\title{
Do Purchase Strategy and Relational Embeddedness Affect Customer Responsiveness on Fashion Manufactures in Yogyakarta
}

\author{
Budi Setyanta \\ Program Studi Manajemen \\ Fakultas Ekonomi dan Bisnis Universitas \\ Janabadra \\ Yogyakarta, Indonesia \\ budi@janabadra.ac.id \\ Mohamad Najmudin \\ Program Studi Manajemen \\ Fakultas Ekonomi dan Bisnis Universitas \\ Janabadra \\ Yogyakarta, Indonesia \\ najmudin@janabadra.ac.id
}

\author{
Nurwiyanta \\ Program Studi Manajemen \\ Fakultas Ekonomi dan Bisnis Universitas \\ Janabadra \\ Yogyakarta, Indonesia \\ nurwiyanta@janabadra.ac.id \\ Eni Andari \\ Program Studi Manajemen \\ Fakultas Ekonomi dan Bisnis Universitas \\ Janabadra \\ Yogyakarta, Indonesia \\ eniandari@janabadra.ac.id
}

\begin{abstract}
This study aims to identify the role of purchasing strategy and relational embeddedness in customer responsiveness. This research is vital because changes in consumer behavior affect the company's action in managing supply chains. This study used a convenience sampling technique to take 100 samples through a questionnaire and uses the structural equation model to test the hypothesis. The results indicate that the purchasing strategy affects the company's ability to build strong relationships that support the speed of serving customer needs. Also, the ability to build strong relationships in the supply chain affects the response of serving customer needs.
\end{abstract}

Keywords: Purchasing Strategy, Relational Embeddedness, Customer Responsiveness

\section{INTRODUCTION}

The purchasing strategy a more strategic role because it is responsible for product development activities through harmonizing purchasing and production [11]; [16];[10]. The purchasing tactic a role in developing a sustainable competitive advantage through effective supply chain management. The right purchasing tactics make it easier for companies to achieve their targets through cost advantages, product quality, fast delivery, and customer responsiveness [1]; [2]. Companies limit mutual trust with several suppliers to facilitate the sharing of information, risks, benefits, and maintain long-term relationship commitments [3] because the relational embeddedness has a positive effect on customer responsiveness [4] . Fashion manufacture has a local market and builds positive interactions with customers. Strong emotional customer ties ensure the continuity of the business relationship. To overcome the constraint of raw material availability, fashion manufacturers make direct contact to understand the various tastes of customers. Variations in customer choices have an impact on purchasing strategies and the supply of raw materials. The ability to identify customer tastes can help define purchasing and production strategies.

\section{LITERATURE REVIEW}

A. The impact of the purchasing strategy on relational embeddedness.

Purchasing strategy is part of supply chain management [5], also one of the essential functions for companies that will support the company's competitive advantage [1]; [17] ;2]. The purchasing strategy plays a role in enhancing close relationships with several suppliers and enhancing substantial commitment and trust [3]. The purchasing tactics have a positive effect on relational embeddedness because promise and credence will reduce conflict, increase decision-making ability in times of uncertainty, and reduce the potential for the end of cooperation.

H1: The purchasing strategy has a positive effect on relational embeddedness

\section{B. The effect of relational embeddedness on customer responsiveness?.}

Relational engagement is an informal relationship between buyers and suppliers that can reduce the negative impact of uncertainty. Suppliers receive complete and accurate information from customers and use it to develop a service strategy that provides convenience and benefits to customers [12]; [6]. Suppliers serve customers to solve their problems in the best way, indicates that relational embeddedness has a positive effect on customer service innovation which benefits both parties [3] H2: Relational embeddedness has a positive effect on customer responsiveness 


\section{The influence of purchasing strategies on customer responsiveness?}

The purchasing strategy has a vital role in the production process [3]. Companies use purchasing strategies to anticipate uncertainty [7], reduce distribution costs [5], create value through purchasing inputs, providing services and facilities needed to produce products [8] .The purchasing strategy is part of the company's supply chain management and is integrated with other departments and requires synergy to create company profits [5]; [9] The integration of purchasing strategies has an impact on reducing costs, inventory, employment and administration, as well as improving customer service [11]; [16] ;[10]. [8]. found that the right purchasing strategy can improve company performance because it has a positive effect on customer responsiveness.

H3: The purchasing strategy has a positive impact on customer responsiveness

\section{RESEARCH METHOD}

The population in this study was fashion manufacture in Yogyakarta with a sample size of 100 . This study used a convenience sampling technique through a questionnaire. To measure the degree of suitability between the hypothesized model and the data presented using the Goodness-of-fit test [14]. Hypothesis testing using the structural equation model.

\section{RESEARCH RESULTS}

\section{A. Goodness-of-Fit}

\section{TABLE I. GOODNESS-OF-FIT CRITERIA}

\begin{tabular}{|l|c|c|c|}
\hline \multicolumn{1}{|c|}{ Indexs } & Cut-off & Value & Critria \\
\hline Goodness of Fit Index (GFI) & $\geq 0,90$ & 0,921 & Fit \\
\hline Comparative fit index (CFI) & $\geq 0,95$ & 0,97 & Fit \\
\hline Tucker-Lewis Index (TLI) & $\geq 0,95$ & 0,965 & Fit \\
\hline
\end{tabular}

Goodness-of-fit is a statistical model that describes how to fit the model developed with research data is [15]. and is used to test whether the developed model can explain the data according to the underlying theory [18].

The fit model test uses several indicators and not a single parameter. This study uses several parameters as follows. The Goodness of Fit Index (GFI) reflects the overall level of suitability of the predicted model compared to the actual data. The GFI value ranges from $0-1$, where 0 indicates poor fit and 1 indicates a perfect fit. The Goodness of Fit Index (GFI) recommends a point $>0.9$. This research model has a fit level of suitability because the GFI value is $0.921>0.9$

Comparative Fit Index (CFI) is an incremental fit index that compares the tested model with the null model. The magnitude of this index is in the range of 0 to 1 . The Comparative Fit Index (CFI) is relatively insensitive to sample size and resists the complexity of the model. The Comparative Fit Index (CFI) recommends a value> 0.9. This study has a model fit because the Comparative Fit Index (CFI) value is $0.970>0.95$.
The Tucker Lewis Index (TLI) is an additional suitability index that compares the tested model with the null model and denotes a value> 0.9. This research has model suitability because the Tucker Lewis Index (TLI) value is $0.965>0.9$

\section{B. Hypothesis Testing and Discussion}

TABLE II. REGRESSION TEST RESULTS

\begin{tabular}{|lll|c|c|c|c|}
\hline \multicolumn{2}{|c|}{ Variable } & $\begin{array}{c}\text { Estim } \\
\text { ate }\end{array}$ & $\begin{array}{c}\text { S.E } \\
\text {. }\end{array}$ & $\begin{array}{c}\text { C. } \\
\text { R }\end{array}$ & P \\
\hline $\begin{array}{l}\text { Relational } \\
\text { Embedded } \\
\text { ness }\end{array}$ & -- & $\begin{array}{l}\text { Purchasin } \\
\text { g Strategy }\end{array}$ & 0.304 & $\begin{array}{c}0.1 \\
02\end{array}$ & $\begin{array}{c}3.0 \\
22\end{array}$ & $\begin{array}{c}0.0 \\
17\end{array}$ \\
\hline $\begin{array}{l}\text { Customer } \\
\text { Responsiv } \\
\text { eness }\end{array}$ & -- & $\begin{array}{l}\text { Relational } \\
\text { Embedde } \\
\text { dness }\end{array}$ & 0.217 & $\begin{array}{c}0.2 \\
27\end{array}$ & $\begin{array}{c}2.9 \\
53\end{array}$ & $\begin{array}{c}0.0 \\
36\end{array}$ \\
\hline $\begin{array}{l}\text { Customer } \\
\text { Responsiv } \\
\text { eness }\end{array}$ & -- & $\begin{array}{l}\text { Purchasin } \\
\text { g Strategy }\end{array}$ & 0.165 & 0.2 & 2.0 & 0.0 \\
01 & 03 & 44 \\
\hline
\end{tabular}

Table II shows that the purchasing strategy has a positive effect on relational embeddedness. H1 is supported.

This study indicates that the purchasing strategy plays a role in developing supply management capabilities including, establishing close working relationships with several suppliers, increasing open communication between parties involved in the supply chain, and developing mutually beneficial long-term strategic relationships. The purchasing strategy encourages and facilitates close relationships with some suppliers. Close relationships ensure supply. The company seeks to maintain long-term relationships with suppliers to create mutual commitment and trust.

The purchasing strategy has evolved, starting from the purchasing plan as a separate function, then developing into a procedure that determines suppliers, the role of purchasing strategies to reduce overall production costs, the role of raw material management to anticipate raw material procurement problems, and the role of current purchasing strategies is as part of supply chain management. The synergy of the purchasing function with other functions within the company through supply chain management makes the purchasing plan an essential part of the company that will support the company's competitive advantage. The purchasing department must understand well the company's strategy because of the purchasing department's functions in synergy with other departments.

Table II shows that relational embeddedness has a positive effect on customer responsiveness. $\mathrm{H} 2$ is supported.

The results of this study indicate that relational embeddedness has a positive effect on the company's ability to increase customer responsiveness. Relational embeddedness is a strong social bond and a significant impact on the economic behavior of the parties involved. Social relationships between companies and suppliers tend to be long term and affect company performance. 
Relational embeddedness increases the exchange of information and mutual understanding between the parties working together, which has an impact on increase company performance. Relational embeddedness is the basis for coordination and information exchange in managing vital resources and interrelated activities between companies and suppliers. Companies are required to provide services to help customers, so the company must be able to identify and solve customer problems. Close company relationships will create intensive interactions and generate trust so that customers will volunteer to provide information about their needs and wants.

Table II shows that the purchasing strategy has a significant effect on relational embeddedness. H3 is supported.

The results of this study indicate that the purchasing strategy has a positive effect on customer responsiveness. The purchasing plan is part of a business strategy that can reduce production costs and improve customer service. Purchasing strategies can improve company performance and have a positive effect on customer responsiveness. The purchasing plan plays a primary role in creating company value and anticipating changing customer needs. The purchasing strategy has a broader function, namely determining the product, the number of products, the right time and place of delivery, and the appropriate source. The role of a more complex purchasing strategy supports company performance because it determines priorities in operations with a focus on quality, cost, production time, new product introduction, delivery speed, reliability, and customer responsiveness

\section{CONCLUSION}

This study found that purchasing strategy positively and significantly impacts relational embeddedness. Moreover, the result also confirm the relationship between relational embededness and customer responsiveness. Finally, this framework reported that purchasing strategy positively and significantly affects customer responsiveness.

\section{IMPLICATION}

Companies need to develop a purchasing strategy that can increase the closeness of the relationship with suppliers. Companies and suppliers need to promote open communication and develop a long-term strategic orientation to achieve mutual benefits.

The closeness of the relationship and the right purchasing strategy affect the company's ability to meet customer needs quickly. The speed to respond and meet customer needs is a primary aspect of customer responsiveness. The rate in meeting these needs affects the company's competitive advantage and is a primary factor affecting the company's performance.

\section{REFERENCES}

Chain Manag., vol. 36, no. 1, pp. 17-28, 2000, doi: 10.1111/j.1745-493X.2000.tb00074.x.

[2] S. Martínez, M. Mediavilla, J. Bäckstrand, and C. Bernardos, "Alignment of the Purchasing Strategy to the Business Strategy: An Empirical Study on a Harbour Cranes Company," IFIP Adv. Inf. Commun. Technol., vol. 440, no. PART 3, pp. 51-58, 2014, doi: 10.1007/978-3-662-44733-8_7.

[3] I. J. Chen, A. Paulraj, and A. A. Lado, "Strategic purchasing, supply management, and firm performance," J. Oper. Manag., vol. 22, no. 5, pp. 505-523, 2004, doi: 10.1016/j.jom.2004.06.002.

[4] D. A. Johnston, D. M. McCutcheon, F. I. Stuart, and H. Kerwood, "Effects of supplier trust on performance of cooperative supplier relationships," J. Oper. Manag., vol. 22, no. 1, pp. 23-38, 2004, doi: 10.1016/j.jom.2003.12.001.

M. R. Monczka, R. J, and et all, "Supply Base Strategies to Maximize Supplier Performance," Int. J. Phys. Distrib. Logist. Manag., vol. 23, no. 4, pp. 42-54, 1993, doi: $10.1108 / 09600039310041509$.

[6] J. Agyei, S. Sun, E. Abrokwah, E. K. Penney, and R. OforiBoafo, "Influence of Trust on Customer Engagement: Empirical Evidence From the Insurance Industry in Ghana," SAGE Open, vol. 10, no. 1, 2020, doi: $10.1177 / 2158244019899104$.

[7] P. D. Cousins, "The alignment of appropriate firm and supply strategies for competitive advantage," Int. J. Oper. Prod. Manag., vol. 25, no. 5, pp. 403-428, 2005, doi: $10.1108 / 01443570510593120$.

P. Thrulogachantar and S. Zailani, "The influence of purchasing strategies on manufacturing performance: An empirical study in Malaysia," J. Manuf. Technol. Manag., vol. 22, no. 5, pp. 641-663, 2011, doi: $10.1108 / 17410381111134482$.

[9] E. Sabet, N. Yazdani, and S. De Leeuw, "Supply chain integration strategies in fast evolving industries," Int. J. Logist. Manag., vol. 28, no. 1, pp. 29-46, 2017, doi: 10.1108/IJLM01-2015-0013.

[10] A. Brandon-Jones and D. Knoppen, "The role of strategic purchasing in dynamic capability development and deployment: A contingency perspective," Int. J. Oper. Prod. Manag., vol. 38 , no. 2, pp. 446-473, 2018, doi: 10.1108/IJOPM-10-2015-0656.

[11] K. Thawiwinyu., Laptaned, U, The Impact of Strategic Sourcing and E-Procurement on Supply Chain Performance Management,The 20th National Conference of Australian Society for Operations Research \& the 5th International Intelligent Logistics System Conference: 106.1 - 106.12, 2009.

[12] B. Uzzi., Lancaster, Ryon. Embeddedness and Price Formation in the Corporate Law Market, American Sociological Review, (69)3 (Jun):319-344, 2003.

[13] J. Yoon., and Moon, Junyean,"The moderating effect of buyer purchasing strategy on the relationship between supplier transaction-specific investment and supplier firm performance," Journal of Business Research, Elsevier, vol. 99(C), pages 516-523, 2019. doi: 10.1016/j.jbusres.2017.08.022

[14] A. Ferdinand, Metode Penelitian Manajemen: Pedoman 
Penelitian Untuk Skripsi, Tesis dan Disertasi ilmu Manajemen. Badan Penerbit Universitas Diponegoro. Semarang, . 2014.

[15] M. Olivares, A., G. Forero, C, Goodness-of-Fit Testing. International Encyclopedia of Education, 7: 190-196,2010.

[16] G. Hawkins, T., M. Gravier., D. Berkowitz, \& W. Muir, Improving services supply management in the defense sector: How the procurement process affects B2B service quality, Journal of Purchasing and Supply Management, 21, 81-94,2015.

[17] P. Hong. and H-B Kwon , "Emerging issues of procurement management: a review and prospect", Int. J. Procurement Management, Vol. 5, No. 4, pp.452-469,2012.

[18] D Hooper, J. Coughlan, Mullen, M. R, Structural Equation Modelling: Guidelines for Determining Model Fit, Electronic Journal of Business Research Methods Volume, 6( Issue 1): 53-60,2008. 